\title{
Survival problems of archaeophytes in the Polish flora
}

\author{
Maria Zając* \& Adam Zając
}

Institute of Botany, Jagiellonian University, Kopernika 27, 31-501 Kraków, Poland

* corresponding author (e-mail: maria.zajac@uj.edu.pl)

\begin{abstract}
These considerations have been based on the updated list of archaeophytes appearing in Poland. The extent of endangerment has been assessed for particular species according to the updated IUCN classification. Non-threatened and invasive species have also been taken into consideration. A number of quite fundamental changes have been made to the classification, as compared to the publication of Zając et al. of 2009.
\end{abstract}

Key words: archaeophytes, endangerment, expansion, Polish flora, new checklist

\section{Introduction}

Changes which occur in the modern flora of the world, i.e. the decline of stenotopic elements on the one hand, and the expansion of eurytopic elements on the other, belong to the most commonly depicted phenomena of modern times. The distinction between native and alien elements and the observation of their relations result in attempts to save the former and the wish to remove the latter ones. The division of anthropophytes (archaeophytes) introduced by Thellung $(1915,1918-19)$ and then adapted in Poland with some modifications made by Kornaś (Kornaś \& Medwecka-Kornaś 2002), allows to follow the history of the old anthropophytes (archaeophytes) in the florae of different areas. We limit ourselves to Poland and try to answer the question what their situation is like in the contemporary flora. Certainly, some of them, especially those extinct or critically endangered, have been the subject of a number of works (e.g. Anioł-Kwiatkowska \& Szczęśniak 2011). However, we wish to review their complete set and to discuss the forecasts for the future and possible measures to be taken by the man aimed at the depletion of archaeophyte flora to be prevented.

This work constitutes a continuation of the paper published in BRC five years ago (Zając et al. 2009). Quite significant modifications have occurred as compared to that work with respect to allocating to particular endangerment groups, whereby some slight changes should be noticed in the list of archaeophytes itself.

\section{Methodical notes}

It is a relatively complete list of archaeophytes appearing in Poland which should be the basis of considerations. One of the co-authors of this paper (Zając $1979,1983,1987 \mathrm{a}, 1987 \mathrm{~b}, 1988)$ attempted to establish a complete list in 1970s and 1980s. Some modifications have been introduced since then which cover in total less than $10 \%$ of the list. Their contemporary, most complete list can be found in the book covering all anthropophytes reported from Poland, where the present authors listed, inter alia, the data for archaeophytes (Tokarska-Guzik et al. 2012). The present list contains some changes with respect to several species, as compared to the previous one. It must be stressed that different Polish authors are of divergent opinion as to particular species to fall into or to be excluded from the archaeophyte group (e.g., Celka 2011; Woch 2012). This problem requires further research work so we accept the author's list to be the basis of this paper.

Methodical problems of classifying into the archaeophyte group were discussed in the previous paper (Zając \& Zając 2011). It should be stressed that over 77 per cent of them have archaeobotanical documentation as far as the age is concerned (Zając \& Zając 2011). It is more difficult to determine the IUCN-based endangerment category for archaeophytes, as compared to native species. Though the problem of disappearance of segetal weeds is supported by rich documentation, there is no data regarding archaeophytes appearing 
in ruderal habitats. Research regarding synanthropic florae of urban areas has never been a popular field of study in Poland. Principally, several florae can be mentioned which were investigated in large cities (SudnikWójcikowska 1987; Jackowiak 1993; Tokarska-Guzik 1999; Witosławski 2006), where more or less complete floristic documentation existed before. Apart from few exceptions (Wołkowycki 2000), there are no such works regarding areas of small towns or villages from a larger region. The question about the behaviour of particular species can only be answered by several years' exhaustive floristic study of an area where the whole vascular flora and the distribution of all its components have been explored in a methodical way. Then, we can say how the archaeophyte flora looks like presently in a given area and, if some historical data is available, we can make some reference to its dynamics. The possibility of finding some new stands of the endangered archaeophytes was also indicated by some detailed field research works (e.g., Szeląg 1997; Nobis et al. 2010).

A number of studies carried out in Małopolska Upland, Sandomierz Lowland and in the Carpathians were used, as detailed floristic monographs including the research into their distribution within a cartogram net, in order to determine the present condition of several dozens of archaeophytes in Polish flora (Towpasz 2006; Nobis 2007; Nobis 2008; Piwowarczyk 2010; Stawowczyk 2010; Binkiewicz 2012; Pierścińska 2014; Wolanin 2014). Unfortunately, there are no contemporary studies of this type so our information about the condition of a given species had to be based on a number of sources which may give some out-of-date information. It shows the need of very detailed field research works to be carried out in many parts of Poland and, with respect to archaeophytes, especially in Lower Silesia where only one floristic work covering a larger area has been published recently (Kwiatkowski 2006).

The IUCN-based scale, slightly modified for the needs of this paper, was used for the assessment of endangerment of particular species. The question of the appearance of a given species in different habitats or even its tendency in this direction was found to be an important assessment factor. In our opinion, it enhances the chance of a given archaeophyte to be preserved in our flora. There are no data regarding several species. For example, it is the case regarding sub-species of two taxa of Rhinathus genus. They were not determined even in the modern florae, therefore it is necessary to collect herbarium materials including ripe seeds for their inventory.

\section{Results}

The results of archaeophytes classification from Appendix 1 are shown in Fig. 1. Three subgroups were distinguished there in each category, i.e. archaeophytes appearing in segetal habitats, archaeophytes appearing in both segetal and ruderal habitats and archaeophytes of ruderal habitats. In Appendix 1, an additional designation was used in the upper index at the end of segetal archaeophyte names in the case of species which showed a weak tendency to appear sometimes in ruderal habitats, e.g. near railway lines.

\subsection{Extinct species}

Three species of archaeophytes were classified as extinct. Two of them, i.e. Camelina alyssum and Cuscuta epilinum, are specialized weeds of flax cultivation which perished as a result of the use of effective seed purification methods and efficient herbicides. Only one species of the extinct archaeophyte, i.e. Camelina alyssum can be found in the Polish Red Book (Mirek 2001). The third of the extinct species, i.e. Vaccaria hispanica used to have numerous stands in Poland (approx. 300 stands were reported in literature). Like the two above-mentioned species, it was a speirochore and the effective method of seed purification eliminated this species from the established flora of Poland. Only segetal species belong to the extinct archaeophytes in Poland. In the paper of 2009 (Zając et al. 2009), we classified five species as extinct. Stachys arvensis was placed in the group of critically endangered species and Spergula arvensis subsp. maxima was included in the group of species about which no credible information was available; that group is discussed below. We can suppose this group to increase significantly, as a number of the taxa of critically endangered archaeophytes have a chance to largely enrich it.

\subsection{Critically endangered species}

In this paper, two groups were distinguished among critically endangered species which differ in their scopes in Poland. The first one, which is discussed below, covers the species whose range is limited to certain regions of Poland. It results from their habitatrelated preferences as they are only segetal weeds tied to the soil which has high calcium carbonate content and appear in the regions of the country with a warmer climate. In all, 14 species were classified in that group but there were differences between them in terms of the number of stands and the possibility to find more stands. Such species as e.g. Adonis flammea or Thymelaea passerina can be found as single specimens. Others, as for example Scandix pecten-veneris or Allium rotundum can sometimes surprise, as they were found in new stands in hundreds of specimens (Zając et al. mscr a, mscr b). The remaining species can be found from time to time during field research works, as for example Nigella arvensis which was reported several times in the research carried out in the first decade of the 


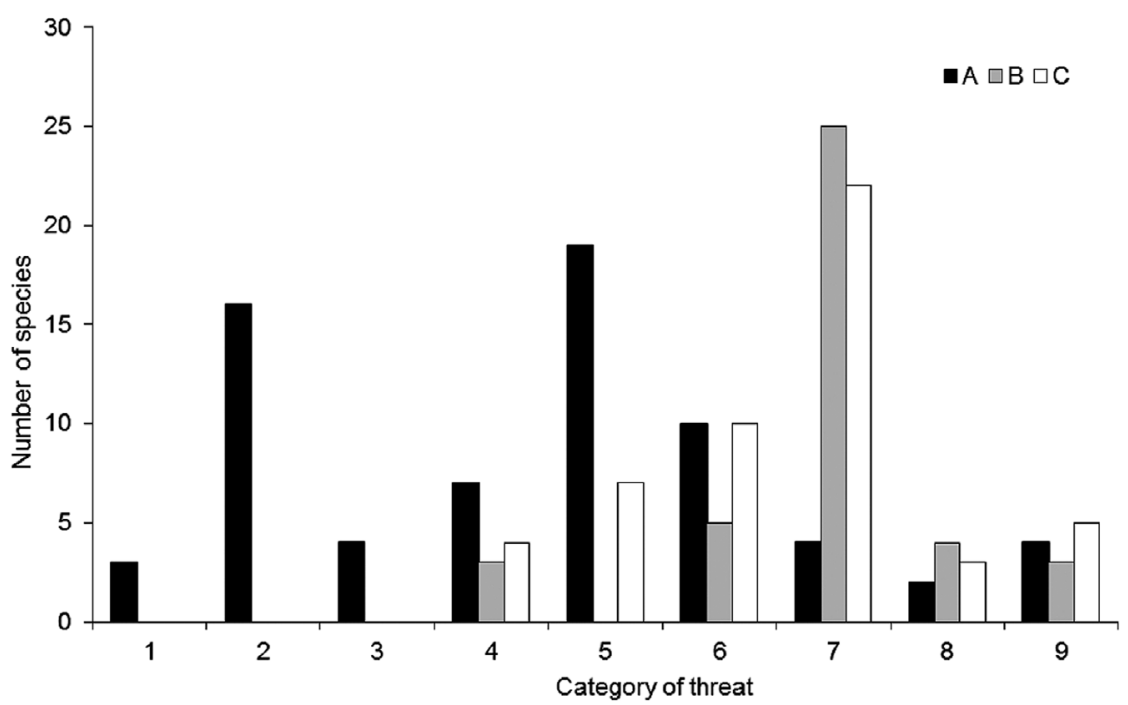

Fig 1. Number of species in the threatened categories

Explanations: 1 - extinct, 2 - critically endangered of limited range in Poland, 3 - critically endangered in the whole range in Poland, 4 - endangered, 5 vulnerable, 6 - with the number of localities decreasing, 7 - with stable dynamics, 8 - expansion of species observed, sometime invasive, 9 - lack of data about species (data deficient); $\mathrm{A}$ - segetal species, B - species of ruderal and segetal habitats, $\mathrm{C}$ - ruderal species

$21^{\text {st }}$ century (Towpasz 2006; Nobis 2007; Piwowarczyk 2010). In total, seven new stands were reported in those three studies. In the previous paper (Zając et al. 2009), Stachys arvensis, a species appearing in Poland and having two main appearance centres in Lower Silesia and Gdańsk Pomerania, was classified in the group of extinct species. According to Dajdok and Śliwiński (2011), it has two confirmed stands in Lower Silesia. Therefore, it was moved to the group of critically endangered species.

The second group of species with larger scopes in Poland covered five segetal species. Only one of them, i.e. Lolium remotum was indicated to be characteristic for flax cultivations. However, it had the largest ecological scale of all flax specialists. Linaria arvensis, a weed reported from sandy fields, often with a greater content of calcium carbonate, presently has only several or a dozen of stands in Poland. The two remaining taxa are two species from the genus of Rhinanthus alecterolophus subsp. buccalis and Rh. serotinus subsp. apterus which are speirochores. The seeds of those subspecies are adapted to be disseminated along with grain seeds. We think these taxa to be critically endangered, although subspecies are seldom determined in current floristic works. For their identification, it is necessary to collect plant herbarium materials, including ripe seeds, which, unfortunately, most researchers do not do. However, the general process of speirochore disappearance due to the effective seed purification made us place them, as before, in the group of critically endangered species. The new archaeophyte species called Orobanche ramosa, which has only two stands in Poland at present (Piwowarczyk 2012), was also allocated to that group. This species is supposed to have been the parasite Cannabis sativa in the past.

It is difficult to predict the chance of the whole group of critically endangered species. Although they showed a high habitat-related and phytosociological community, detailed research may result in a change in endangerment degree for particular species. A paper from 2009 covered 13 species classified in the group of critically endangered ones. Presently, 18 species were placed in two subcategories of critically endangered ones, whereby 10 of them did not change their endangerment status. Three species, i.e. Chrysanthemum segetum (in the group of endangered species), Conringia orientalis (in the group of endangered species) and Erysimum repandum (in the group of species with no information available), were classified in a different way in this paper.

\subsection{Endangered species}

This category covers 15 species. In the abovediscussed category of critically endangered species, there were taxa which appeared in segetal habitats only. Among the endangered species, 9 appeared only in segetal habitats, 4 - in ruderal habitats and two were recorded in both segetal and ruderal habitats. In the previous paper (Zając et al. 2009), that group covered 16 species. There were only 6 coinciding species, i.e.: Anagalis foemina, Chenopodium opulifolium, Ch. urbicum, Ch.vulvaria, Herniaria hirsuta and Veronica opaca. The status of several species was raised in the present list by moving them to the group of critically endangered species. They comprised: Bupleurum rotundifolium, Galium tricornutum, Kickxia spuria and Thymelaea passerina. The following taxa were moved to the group of perishing 
species from that of the endangered ones: Adonis aestivalis, Bromus arvensis, Lolium temulentum, Misopates orontium, Parietaria officinalis, Pisum sativum subsp. arvense and Silene gallica. The degree of endangerment was lowered for the following species by considering them to be vulnerable ones: Chenopodium murale, Coronopus procumbens, Fumaria schleicheri and $\mathrm{Ga}$ gea arvensis. Significant changes in this group of recession species were the result of detailed studies on recent reports concerning the above-mentioned archaeophytes and field research work carried out within their scopes in Poland (e.g. Anioł-Kwiatkowska \& Szczęśniak 2011). The species which used to be quite common, e.g. Silene gallica, a cereal and root crop weed in Southern Poland, recently became extremely rare (Stawowczyk 2010; Anioł-Kwiatkowska \& Szczęśniak 2011, Binkiewicz 2012). Other species, such as e.g. Fumaria schleicheri, a taxon which had never been common in Poland and which used to be tied to segetal communities, became an almost ruderal species and that is where it can be found most frequently.

\subsection{Vulnerable species}

In this paper, 26 archaeophyte species were classified in this group. As far as their habitat-related preferences are concerned, 18 species appeared only in segetal communities and 8 of them - in ruderal habitats. In the previous paper (Zając et al. 2009), 31 species were classified in this group. Two of them, i.e. Marubium vulgare and Portulaca olercea were excluded from the archaeophyte group (Tokarska-Guzik et al. 2012); 15 species were found on both lists, i.e.: Aethusa cynapium subsp. agrestis, Agrostemma githago, Anthemis cotula, Anthriscus cancalis, A. cerefolium, Atriplex rosea, Camelina sativa, Chamomilla recutita, $\mathrm{Me}$ landrium noctiflorum, Neslia paniculata, Ranunculus arvensis, Stachys annua, Valerianella rimosa, Veronica agrestis and $V$. polita. The endangerment group was raised in this paper for over a dozen of species; thus Euphorbia falcata and Kickxia spuria which are disappearing quickly in all their scopes in Poland, were moved to the group of critically endangered species, and 7 species, i.e. Adonis aestivalis, Bromus arvensis, Lolium temulentum, Misopates orontium, Parietaria officinalis, Pisum sativum subsp. arvense and Silene gallica were moved to the group of extinction-threatened species. The remaining 7 species were classified in the groups of lower risk or even as unendangered ones. Such changes introduced in a relatively short time were necessary because of the intensive process of disappearance of stands of particular species, whereby the new field research work allowed to reassess the endangerment.

\subsection{Species showing signs of recession}

It is a group of species classified, according to IUCN, as taxa of lower risk. The group covers 25 species. It comprises taxa which were moved from the category of vulnerable ones, such as e.g. Camelina microcarpa subsp. sylvestris, Chenopodium ficifolium, Fumaria vaillantii or Lathyrus tuberosus, and those whose number of stands decreased as compared to the earlier

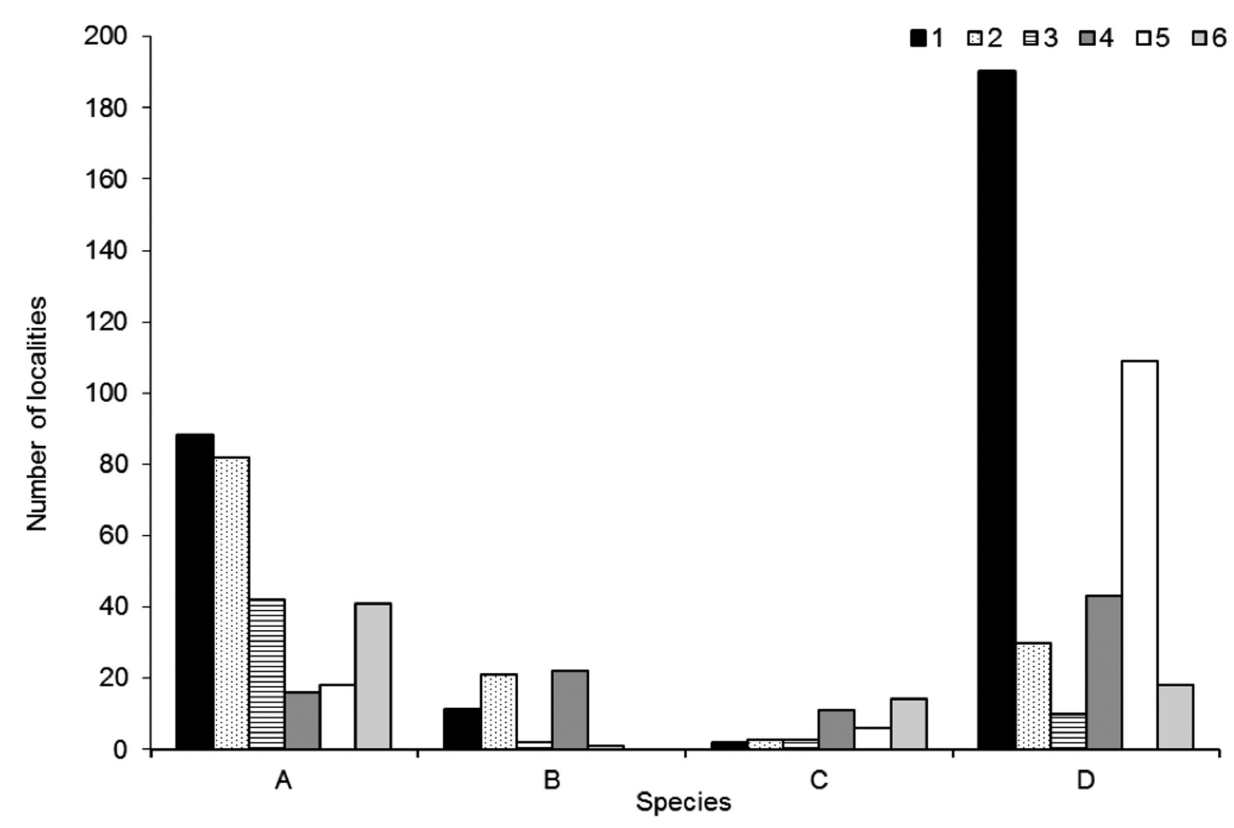

Fig. 2. Number of localities of the selected species of archaeophytes in the different areas of Poland

Explanations: A - Camelina microcarpa subsp. microcarpa, B - Chenopodium ficifolium, C - Fumaria vaillantii, D - Lathyrus tuberosus; vascular flora of the (1) Proszowice Plateau (Małopolska Upland (Towpasz 2006), (2) eastern part of the Iłża Foreland (Małopolska Upland) (Piwowarczyk 2010), (3) western part of the Iłża Foreland (Małopolska Upland) (Nobis 2007), (4) eastern part of the Sandomierska Basin (Nobis 2008), (5) eastern part of Połaniec Basin (Małopolska Upland) and adjacent part of the Nadwiślańska Lowland (Sandomierz Basin) (Pierścińska 2014), (6) eastern part of Niecka Włoszczowska (Bielecki 2011) 
period. Such losses do not constitute any threat for the species presence in Poland, but they draw our attention to those species. This group covered 10 species of segetal weeds, 10 species of ruderal habitats and 5 species appearing in both of the above-mentioned habitats. In field research carried out in recent years many species from this group were confirmed to have numerous stands of large specimen populations. Examples of population numbers in the areas covered by recent field research are shown in the diagram prepared for the taxa whose endangerment category was lowered. They are presented in Fig. 2. Very high numbers of new stands were reported, especially for two species, i.e. Camelina microcarpa and Lathyrus tuberosus. The lowest numbers of new stands were confirmed for Fumaria vaillantii, but this species was never common, and still many of its stands were found in ruderal areas, e.g. near railway lines. Chenopodium ficifolium occupied some specific habitats in the areas covered by the research work, as it appeared mainly in river valleys. Probably, that was the reason of its smaller population. Questions were also asked if this list should cover Leonurus cardiaca. Apart from taxonomic problems, i.e. the failure to distinguish L. villosus in Poland which is common in the eastern part of our country (oral information by M. Nobis), this species is disappearing, especially in rural areas where the lack of its habitats begins to be a problem.

\subsection{Stable species (showing no expansion or decrease in the number of stands)}

It was the most numerous group covered by this paper. It comprised 49 archaeophyte species. Only two of them were tied with segetal habitats and included Avena fatua and Bromus secalinus. The most numerous group (26 species) contained species of a wide ecological scale which appeared in both segetal and ruderal habitats. The remaining 22 species were taxa tied to ruderal habitats. The group of archaeophytes stable in their dynamic tendencies comprised the most common of them. The range of 25 species covered the whole territory of Poland; several of them were rare, e.g. Descurainia sophia, Papaver argemone, P. dubium in the Polish Carpathians. A number of the remaining archaeophytes from this group were rather rare in northeastern part of Poland. Anyway, that is how their ranges were shown by ATPOL (Zając \& Zając 2001). Current research by Pliszko (2014) showed this gap to be the consequence of the lack of information, as a number of species turned out to be quite common in the western part of Suwałki Lakeland. ATPOL research filled that gap with stands of the following species: Lactuca serriola, Lamium album, L. amplexicaule, Malva neglecta, Papaver rhoeas, Senecio vulgaris, Sonchus oleraceus, Vicia hirsuta and $V$. villosa.

\subsection{Archaeophyte species showing current growth of expansion dynamics}

Archaeophytes which showed growth in the number of stands or possibly occupied some new habitats may be called invasive. There is a certain difference in our definition of the invasive species, as compared to that of Tokarska-Guzik (2005); we consider a taxon to be invasive when it penetrates semi-natural and natural communities. There were 9 such species in our list. Recently, careful attention was paid to propagation of Alopecurus myosuroides in segetal communities (Korniak \& Szubstarski 2001; Dajdok \& Szczęśniak 2009; Nobis 2010; Trzcińska-Tacik \& Stachurska-Swakoń 2011), i.e. the species whose range was rather associated with the western part of Poland. Such species as Artemisia absinthium and Bromus sterilis enter lawns in areas where xerothermic plants appear and they become a big problem in certain protected objects, e.g. in "Bielinek on the Odra River" nature reservation (own observation). Echinochloa crus-galli enters aquatic (bulrush) communities in certain regions of Poland which is a big problem. This species shows a significant diversity in its native land, i.e. in south-eastern Asia. It can be, simultaneously, both a weed of rice fields and a natural component of bulrushes and communities with Bidens (alliances - Phragmition and Bidention tripartiti). The phenomenon of archaeophytes appearing as invasive species in literal sense is something new and it was observed in Poland during last thirty years and this process seems to become more intensive at present.

\subsection{Species for which no information is available}

11 species can be found in that quite diversified group. The distribution of a number of them is not known as they are often undistinguished, such as e.g. Avena $\times$ vilis or Setaria verticilata. Other species, e.g. Sclerochloa dura, a very rare species in Poland, was found in new stands and in large populations, recently (Nobis 2008). In this situation it was difficult to classify it explicitly. Other species required new taxonomic studies to be carried out, e.g. two deadnettles, i.e. $\mathrm{La}$ mium incisum and L. moluccellifolium. The situation was similar with Solanum alatum and S. luteum. The specimens of nightshades must be picked with ripe fruit and their colour should be noted down when plants are still alive. Spergula arvensis subsp. maxima is treated as flax weed (Anioł-Kwiatkowska \& Szczęśniak 2011). Meanwhile, there are many reports from Central Poland concerning the appearance of this subspecies in cereal communities. Rothmaler (1990) distinguished four subspecies of Spergula arvensis, i.e. subsp. arvensis, subsp maxima, subsp. linicola (Bor.) Janchen and subsp. sativa (Boenn.) Čelak. It is necessary to review materials from Poland and then it can turn out that only subsp. linicola 
became extinct. We hope that the gap resulting from the lack of explicit classification for these species will be filled after floristic and taxonomic research works are completed.

\section{Discussion}

The presented review of archaeophytes appearing in Poland made it possible to formulate certain reliable predictions concerning their future. Critically endangered species are certain to be added to the group of extinct species, if changes in the environment continue to advance at current pace and if they are of total nature, i.e. if they cover most segetal habitats in Poland. Indeed, we can observe a tendency that some of them find their habitats on boundary strips but they are, in turn, threatened by the introduction of large farms. The fact that the endangered species may grow in ruderal habitats may give them a chance to survive. A number of them found their habitats on the outskirts of towns, near railway lines, etc. As a rule, critically endangered species do not show such tendencies.

The endengered and vulnerable species - there may occur continual changes in their classification. Today, we have not any detailed local floristic research at our disposal which would be at a good taxonomic level for most territory of Poland. This causes that data from previous issues of Red Books and Lists are repeated in subsequent editions supplemented with some accidental data. Those archaeophytes which became extinct or critically endangered are seldom worked out in red books (there are only 6 archaeophyte species in the latest II issue). On the one hand, it is the result of the lack of knowledge and, on the other, it stems from our underestimation of cultural and scientific values of this part of flora. When analyzing Figure 1, an obvious relationship can be noticed, i.e. going from the extinct and critically endangered to invasive species, the share of segetal species decreased, while the share of ruderal species and of those which can appear in both these types of habitats increased.

Some program-based activities should cause one or two floristic works to be prepared for each large phytogeographic region of Poland, including a distribution atlas for the taxa contained therein. Some large regions should be chosen for such research projects. A sample of flora for 800 or $1000 \mathrm{~km}^{2}$ is sufficient. Such information should make it possible to adequately monitor the status of preservation of Polish archaeophyte flora in future.

\section{Conclusions}

The endangerment degree of 155 archaeophytes appearing in Poland was analyzed in the paper. Their list, slightly supplemented, was based on the list of Polish anthropophytes which had been published earlier, where we, as co-authors, dealt with the list of this group of species (Tokarska-Guzik et al. 2012). The list shown in this paper is not final but, most probably, it will remain valid for some time.

The archaeophytes were divided into several groups, depending on their endangerment degree or its lack. The following species were found: three extinct species, 14 critically endangered ones, 18 endangered species, 15 vulnerable species, 25 species of lower degree of vulnerability, 49 species with stable dynamics, 10 invasive species and 11 species with an undetermined endangerment degree.

Some significant changes were introduced with respect to the classification of archaeophyte endangerment, as compared to the list published five years ago (Zając et al. 2009). They can be attributed to our current better knowledge of the situation of individual species, which is the result of detailed observations carried out in Lower Silesia and in the Polish Carpathians, and, especially, the appearance of a number of good floristic publications (partly already published), in Małopolska Upland and in Sandomierz Lowland.

We postulate resumption of detailed floristic studies in different geobotanical regions of Poland, because without them verification of the list of endangered species, not only archaeophytes, will be based on data gathered accidentally.

We also postulate collection of seeds from Polish populations of archaeophytes appearing in Poland their storage in cryobanks, picking appropriate samples for molecular research and herbarial materials. It is also necessary to carry out detailed research of archaeophytes in future (e.g. comparing the ones appearing in our country with populations in their native lands). 


\section{References}

Anioł-Kwiatkowska J. \& SzczęŚniak E. 2011. Zagrożone archeofity Dolnego Śląska. Acta Bot. Silesiaca, Suppl. 1: 1-227.

BIELECKI M. 2011. Problemy geobotaniczne i flora roślin naczyniowych wschodniej części Niecki Włoszczowskiej. $\mathrm{Ph}$. D. Thesis, Institute of Botany, Jagiellonian University, Kraków.

BinKIEwicz B. 2012. Rośliny naczyniowe Beskidu Śląskiego. $\mathrm{Ph}$. D. Thesis, Institute of Botany, Jagiellonian University, Kraków.

CELKa Z. 2011. Relics of cultivation in the vascular flora of medieval West Slavic settlements and castels. Biodiv. Res. Conserv. 22: 1-110.

DAJdok Z. \& SzcZę́ŚniaK E. 2009. Występowanie Alopecurus myosuroides (Poaceae) na obszarach rolnych okolic Gilowa na Pogórzu Sudeckim. Fragm. Flor. Geobot. Polonica 16(2): 237-248.

DAJDOK Z. \& ŚLIwiŃSKi M. 2011. Stachys arvensis (Lamiaceae) na Dolnym Śląsku. - gatunek wymierający czy nierozróżniany? Acta Bot. Silesiaca, Suppl. 1: $207-$ 209.

JACKOWIAK B. 1993. Atlas of distribution of vascular plants in Poznań. Publications of the Department of Plant Taxonomy of the Adam Mickiewicz University in Poznań 3: 1-409.

Kornaś J. \& MedweckA-Kornaś A. 2002. Geografia roślin. 634 pp. Wyd. Naukowe, PWN Warszawa.

Korniak T. \& SzUBSTARSKi P. 2001. Alopecurus myosuroides (Poaceae) in cultivated fields of north-eastern Poland. In: L. Frey (ed.). Studies on Grasses in Poland, pp. 229-233. W. Szafer Institute of Botany, Polish Academy of Sciences, Kraków.

Kwiatkowski P. 2006. Current State, separateness and dynamics of vascular flora of the Góry Kaczawskie (Kaczawa Mountains) and Pogórze Kaczawskie (Kaczawa Plateau). I. Distribution atlas of vascular plants. 467 pp. W. Szafer Institute of Botany, Polish Academy of Sciences, Kraków.

Mirek Z. 2001. EX Camelina alyssum (Miller) Thell. - Lnicznik właściwy. In: R. KAŹMIERCZAKOwA \& K. ZARZYCKI (eds.). Polska Czerwona Księga Roślin. Paprotniki i rośliny kwiatowe, wyd. 2, pp. 170-171. PAN, Instytut Botaniki im. W. Szafera, Instytut Ochrony Przyrody, Kraków.

Nobis A. 2008. Rośliny naczyniowe wschodniej części Kotliny Sandomierskiej. Prace Bot. 42: 1-341.

Nobis A. 2010. Alopecurus myosuroides (Poaceae) - gatunek nowy dla flory Kotliny Sandomierskiej Fragm. Flor. Geobot. Polonica 17(1): 179-181.

Nobis M. 2007. Rośliny naczyniowe zachodniej części Przedgórza Iłżeckiego (Wyżyna Małopolska). Prace Bot. 40: 1-458.

Nobis M., Nobis A., Kozak M. \& Przemyski A. 2010. Występowanie Conringia orientalis (Brassicaceae) i Scandix pecten-veneris (Apiaceae) na obszarze Niecki Nidziańskiej. Fragm. Flor. Geobot. Polonica 14(1): 49-59.
PIERŚCIŃSKA A. 2014. Rośliny naczyniowe wschodniej części Niecki Polanieckiej (Wyżyna Małopolska) i przyległej części Niziny Nadwiślańskiej (Kotlina Sandomierska). Prace Bot. 45: 1-354.

Piwowarczyk R. 2010. Rośliny naczyniowe wschodniej części Przedgórza Iłżeckiego (Wyżyna Małopolska). Prace Bot. 43: 1-344.

PiwowARCZYK R. 2012. A revision of distribution and historical analysis of preferred hosts of Orobanche ramosa (Orobanchaceae) in Poland. Acta Agrobot. 65(1): 53-62.

Piwowarski B. 2014. Rośliny naczyniowe Płaskowyżu Jędrzejowskiego (Wyżyna Małopolska). Prace Bot. 46: 1-330.

Pliszko A. 2014. Flora roślin naczyniowych Pojezierza Zachodniosuwalskiego. Prace Bot. 48: 1-349.

Rothmaler W. 1990. Excursionsflora von Deutschland. Bd. 4. Kritischer Ergänzungsband Gefässpflanzen. Volk u.Wissen Volkaeigener Verl. Berlin.

STAWOWCZYK K. 2010. Geobotaniczne aspekty i flora pasma Radziejowej w Beskidzie Sądeckim. Ph. D. Thesis, Institute of Botany, Jagiellonian University, Kraków.

SudNik-Wóscikowska B. 1987. Flora miasta Warszawy i jej przemiany w ciągu XIX i XX wieku. Wyd. UW, Warszawa, 1: 1-242, 2:1-435.

Szeląg Z. 1997. Uzupełnienia do flory Niecki Nidziańskiej. Fragm. Flor. Geobot. Polonica 4: 33-37.

Thellung A. 1915. Pflanzenwanderungen unter dem Einfluss des Menschen. Englers Bot. Jahrb. Leipzig, 53(3/5) Beibl. 116.

Thellung A. 1918-1919. Zur Terminologie der Adventiv- und Ruderalflora. Allg. Bot. Zeitschr. Karlsruhe 24: 36-43.

ToKARskA-Guzik B. 1999. Atlas rozmieszczenia roślin naczyniowych w Jaworznie (Wyżyna Śląska). Prace Bot. 34:1-292.

TOKARSKA-GuZIK B. 2005. The Establishment and Spread of Alien Plant Species (Kenophytes) in the Flora of Poland. Prace naukowe Uniw. Śląskiego w Katowicach 2372: 1-192.

TOKARsKa-GuZIK B., DAJdok Z., ZajĄC M., ZajĄC A., URbisZ A., Danielewicz W. \& Holdyński Cz. 2012. Rośliny obcego pochodzenia w Polsce ze szczególnym uwzględnieniem gatunków inwazyjnych. 197 pp. Generalna Dyrekcja Ochrony Środowiska, Warszawa.

Towpasz K. 2006. Flora roślin naczyniowych Płaskowyżu Proszowickiego (Wyżyna Małopolska). Prace Bot. 39: 1-302.

Trzcińska-Tacik H. \& Stachurska-Swakoń A. 2011. Alopecurus myosuroides (Poaceae) jako trwały chwast pól uprawnych okolic Skały na Wyżynie KrakowskoCzęstochowskiej. Fragm. Flor. Geobot. Polonica 18(2): 221-229.

WitosŁawski P. 2006. Atlas of distribution of vascular plants in Łódź. 386 pp. Wyd. Uniwersytetu Łódzkiego, Łódź.

Woch M. W. 2012. Antropofity znalezione w trakcie badań archeobotanicznych średniowiecznego Krakowa. In: A. Mueller-Bieniek (ed.). Rośliny w życiu codziennym mieszkańców średniowiecznego Krakowa, pp. 
185-209. Instytut Botaniki im. W. Szafera, Polska Akademia Nauk, Kraków.

Wolanin M. 2014. Rośliny naczyniowe Pogórza Przemyskiego i zachodniej części Pogórza Chyrowskiego. Prace Bot. 47: 1-384.

WoŁkowycki D. 2000. Różnicowanie się i ujednolicenie flor ruderalnych w warunkach izolacji środowiskowej. Monogr. Bot. 87: 1-163.

ZAJĄC A. 1979. Pochodzenie archeofitów występujących w Polsce. Rozpr. habil. Uniw. Jagiell, 29: 1-213. Druk UJ w Krakowie.

ZAJACC A. 1983. Studies on the origin of archeophytes in Poland. Part I. Methodical considerations. Zeszyty Nauk. Uniw. Jagiell. 670, Prace bot. 11: 87-107.

ZAJĄC A. 1987a. Studies on the origin of archeophytes in Poland. Part II. Taxa of Mediterranean and AtlanticMediterranean origin. Zeszyty Nauk. Uniw. Jagiell. 790, Prace bot. 14: 7-50.

ZAJAC A. 1987b. Studies on the origin of archeophytes in Poland. Part III. Taxa of Irano-Turanian, Euro-SiberianIrano-Turanian and Medieterranean-Irano-Turanian origin. Zeszyty Nauk. Uniw. Jagiell. 834, Prace bot. 15: 93-129.
ZAJAcC A. 1988. Studies on the origin of archeophytes in Poland. Part IV. Taxa of Pontic-Pannonian, MediterraneoSouth Asiatic, South Asiatic and Middle Europaean origin. Archaeophyta anthropogenea. Archaeophyta resistentia. Archaeophytes of unknown origin. Zeszyty Nauk. Uniw. Jagiell. 872, Prace bot. 17: 23-51.

ZAJĄC A. \& ZAJĄC M. (eds.). 2001. Distribution Atlas of Vascular Plants in Poland. xii+714 pp. Edited by Laboratory of Computer Chorology, Institute of Botany, Jagiellonian University, Cracow.

ZAJACC A. \& ZAJAC M. 2011. Methodical problems in the distinguishing the group of archaeophytes. Acta Bot. Silesiaca 6: 55-62.

ZAJĄC M., ZAJĄC A. \& ToKARSKA-GuZIK B. 2009. Extinct and endangered archaeophytes and the dynamics of their diversity in Poland. Biodiv. Res. Conserv. 13: 17-24.

Zając M., ZajĄC A. \& Binkiewicz B. (mscr. a). CR Allium rotundum L. Czosnek kulisty. Polska Czerwona Księga Roślin.

Zając M., Zając A., Nobis M., Nobis A., Urbisz A. \& ŁaZArski G. (mscr. b) CR Scandix pecten-veneris L. Czechrzyca (Trybulka) grzebieniowa. Polska Czerwona Księga Roślin. 
Appendix 1. List of archaeophytes in Poland with information about their occurrence in various habitats and degree of endangerment

\begin{tabular}{|c|c|c|}
\hline DoE & Name of species & Habitat \\
\hline En & Adonis aestivalis L. & - \\
\hline Crp & Adonis flammea Jacq. & $\bullet$ \\
\hline $\mathrm{Vu}$ & $\begin{array}{l}\text { Aethusa cynapium L. subsp. agrestis } \\
\text { (Wallr.) Dostál }\end{array}$ & $\bullet$ \\
\hline $\mathrm{Vu}$ & Agrostemma githago L. & $\triangleright$ \\
\hline Crp & Ajug a chamaepitys (L.) Schreb. & $\bullet$ \\
\hline Crp & Allium rotundum L. & - \\
\hline $\mathrm{i}$ & Alopecurus myosuroides Huds. & - \\
\hline $\mathrm{Ld}$ & Anagallis arvensis $\mathrm{L}$. & $\diamond$ \\
\hline En & Anagallis foemina Mill. & $\bullet$ \\
\hline $\mathrm{s}$ & Anchusa arvensis (L.) M. Bieb. & $\diamond$ \\
\hline $\mathrm{s}$ & Anchusa officinalis L. & - \\
\hline s & Anthemis arvensis L. & $\Delta$ \\
\hline $\mathrm{Vu}$ & Anthemis cotula L. & 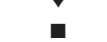 \\
\hline $\mathrm{Vu}$ & Anthriscus caucalis M. Bieb. & 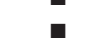 \\
\hline $\mathrm{Vu}$ & Anthriscus cerefolium (L.) Hoffm. & 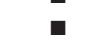 \\
\hline $\mathrm{i}$ & Apera spica-venti (L.) P. Beauv. & 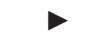 \\
\hline $\mathrm{Ld}$ & Aphanes arvensis L. & $\bullet$ \\
\hline $\mathrm{Vu}$ & Aphanes inexspectata W. Lippert & - \\
\hline $\mathrm{s}$ & Armoracia rusticana P. Gaertn., B. & - \\
\hline $\mathrm{i}$ & $\begin{array}{l}\text { Mey. \& scherb. } \\
\text { Artemisia absinthium L. }\end{array}$ & घ \\
\hline $\mathrm{Vu}$ & Asperugo procumbens L. & - \\
\hline $\mathrm{s}$ & Atriplex nitens Schkuhr & - \\
\hline $\mathrm{Vu}$ & Atriplex rosea L. & a \\
\hline $\mathrm{s}$ & Avena fatua $\mathrm{L}$. & 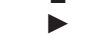 \\
\hline $\mathrm{Vu}$ & Avena strigosa Schreb. & $\bullet$ \\
\hline li & Avena $\times$ vilis Wallr. & - \\
\hline $\mathrm{s}$ & Ballota nigra L. & - \\
\hline En & Bromus arvensis $\mathrm{L}$. & $\checkmark$ \\
\hline $\mathrm{s}$ & Bromus secalinus. & 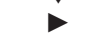 \\
\hline $\mathrm{i}$ & Bromus sterilis L. & . \\
\hline $\mathrm{s}$ & Bromus tectorum L. & - \\
\hline Crp & Bupleurum rotundifolium $\mathrm{L}$. & $\bullet$ \\
\hline Ex & Camelina alyssum (Mill.) Thell. & - \\
\hline $\mathrm{Ld}$ & $\begin{array}{l}\text { Camelina microcarpa Andrz., subsp. } \\
\text { sylvestris (Wallr.) Hiitonen }\end{array}$ & $\bullet$ \\
\hline $\mathrm{Vu}$ & Camelina sativa (L.) Crantz & $\bullet$ \\
\hline $\mathrm{s}$ & Capsella bursa-pastoris (L.) Medik. & a \\
\hline $\mathrm{s}$ & Carduus acanthoides L. & घ \\
\hline $\mathrm{Ld}$ & Carduus nutans L. & $\bar{c}$ \\
\hline Crp & Caucalis platycarpos L. & $\bullet$ \\
\hline $\mathrm{Ld}$ & Centaurea cyanus L. & 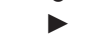 \\
\hline $\mathrm{Vu}$ & Chamomilla recutita (L.) Rauschert & - \\
\hline $\mathrm{Ld}$ & Chenopodium bonus-henricus L. & - \\
\hline $\mathrm{Ld}$ & Chenopodium ficifolium Sm. & - \\
\hline $\mathrm{s}$ & Chenopodium hybridum L. & घ \\
\hline $\mathrm{Vu}$ & Chenopodium murale L. & - \\
\hline En & $\begin{array}{l}\text { Chenopodium opulifolium Schrad. ex } \\
\text { W. D. J. Koch \& Ziz. }\end{array}$ & 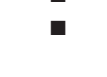 \\
\hline En & Chenopodium urbicum $\mathrm{L}$. & घ \\
\hline En & Chenopodium vulvaria L. & - \\
\hline $\mathrm{Vu}$ & Chrysanthemum segetum $\mathrm{L}$. & 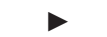 \\
\hline $\mathrm{s}$ & Cichorium intybus L. & - \\
\hline $\mathrm{s}$ & Conium maculatum $\mathrm{L}$. & - \\
\hline Crp & Conringia orientalis (L.) Dumort. & • \\
\hline $\mathrm{Ld}$ & Consolida regalis Gray & 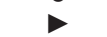 \\
\hline $\mathrm{Vu}$ & Coronopus squamatus (Forssk.) Asch. & - \\
\hline Ex & Cuscuta epilinum Weihe ex Boenn. & $\bullet$ \\
\hline $\mathrm{s}$ & $\begin{array}{l}\text { Descurainia sophia (L.) Webb ex } \\
\text { Prantl }\end{array}$ & $\diamond$ \\
\hline $\mathrm{i}$ & $\begin{array}{l}\text { Digitaria ischaemum (Schreb.) H. L. } \\
\text { Mühl. }\end{array}$ & $\diamond$ \\
\hline s & Digitaria sanguinalis (L.) Scop. & $\diamond$ \\
\hline $\mathrm{i}$ & Echinochloa crus-galli (L.) P. Beauv. & $\Delta$ \\
\hline li & Erysimum repandum $\mathrm{L}$. & घ \\
\hline $\mathrm{Ld}$ & Euphorbia exigua L. & $\bullet$ \\
\hline Crp & Euphorbia falcata $\mathrm{L}$. & $\bullet$ \\
\hline
\end{tabular}

\begin{tabular}{|c|c|c|}
\hline DoE & Name of species & Habitat \\
\hline $\mathrm{s}$ & Euphorbia helioscopia L. & $\diamond$ \\
\hline s & Euphorbia peplus L. & $\diamond$ \\
\hline $\mathrm{i}$ & Fallopia convolvulus (L.) Á. Löve & $\diamond$ \\
\hline $\mathrm{Ld}$ & Fumaria officinalis L. & $\checkmark$ \\
\hline Crp & Fumaria rostellata Knaf & $>$ \\
\hline En & Fumaria schleicheri Soy.-Will. & $\diamond$ \\
\hline $\mathrm{Ld}$ & Fumaria vaillantii Loisel. & $\diamond$ \\
\hline $\mathrm{Vu}$ & Gagea arvensis (Pers.) Dumort. & $\triangleright$ \\
\hline $\mathrm{Ld}$ & Galium spurium L. & $\bullet$ \\
\hline Crp & Galium. tricornutum Dandy & $\bullet$ \\
\hline $\mathrm{Ld}$ & Geranium dissectum $\mathrm{L}$. & 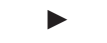 \\
\hline $\mathrm{s}$ & Geranium molle L. & - \\
\hline $\mathrm{s}$ & Geranium pusillum Burm. f. ex L. & - \\
\hline En & Herniaria hirsuta L. & $\bullet$ \\
\hline $\mathrm{i}$ & Hordeum murinum $\mathrm{L}$. & - \\
\hline $\mathrm{Ld}$ & Hyoscyamus niger $\mathrm{L}$. & - \\
\hline $\mathrm{li}$ & Hyssopus officinalis L. & - \\
\hline Crp & Kickxia elatine (L.) Dumort. & D \\
\hline Crp & Kickxia spuria (L.) Dumort. & $\bullet$ \\
\hline $\mathrm{s}$ & Lactuca serriola $\mathrm{L}$. & - \\
\hline $\mathrm{s}$ & Lamium album $\mathrm{L}$. & - \\
\hline s & Lamium amplexicaule $\mathrm{L}$. & $\diamond$ \\
\hline li & Lamium incisum Willd. & 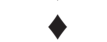 \\
\hline li & Lamium moluccellifolium Fr. & $\diamond$ \\
\hline $\mathrm{s}$ & Lamium purpureum $\mathrm{L}$. & $\checkmark$ \\
\hline $\mathrm{Ld}$ & Lathyrus tuberosus L. & $>$ \\
\hline $\mathrm{Ld}$ & Leonurus cardiaca L. & - \\
\hline $\mathrm{Ld}$ & Lepidium campestre (L.) R. Br. & - \\
\hline $\mathrm{s}$ & Lepidium ruderale L. & - \\
\hline Crw & Linaria arvensis (L.) Desf. & $\bullet$ \\
\hline $\mathrm{Ld}$ & Lithospermum arvense $\mathrm{L}$. & • \\
\hline Crw & Lolium remotum Schrank & $\bullet$ \\
\hline En & Lolium temulentum $\mathrm{L}$. & $\triangleright$ \\
\hline $\mathrm{s}$ & Malva alcea $\mathrm{L}$. & घ \\
\hline $\mathrm{Ld}$ & Malva crispa $\mathrm{L}$. & - \\
\hline $\mathrm{s}$ & Malva neglecta Wallr. & घ \\
\hline $\mathrm{s}$ & Malva pusilla $\mathrm{Sm}$. & 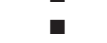 \\
\hline s & Malva sylvestris $\mathrm{L}$ & - \\
\hline $\mathrm{s}$ & $\begin{array}{l}\text { Matricaria maritima L. subsp. inodora } \\
\text { (L.) Dostál }\end{array}$ & $\diamond$ \\
\hline $\mathrm{s}$ & Melandrium album (Mill.) Garcke & $\diamond$ \\
\hline $\mathrm{Vu}$ & Melandrium noctiflorum (L.) Fr. & $\bullet$ \\
\hline En & Misopates orontium (L.) Raf. & $\diamond$ \\
\hline $\mathrm{s}$ & Myosotis arvensis (L.) Hill & $\diamond$ \\
\hline $\mathrm{Ld}$ & Nepeta cataria L. & - \\
\hline $\mathrm{Vu}$ & Neslia paniculata (L.) Desv. & $\bullet$ \\
\hline Crp & Nigella arvensis L. & - \\
\hline $\mathrm{Vu}$ & Odontites verna (Bellardi) Dumort. & - \\
\hline $\mathrm{s}$ & Onopordum acanthium L. & - \\
\hline Crp & Orobanche ramosa $\mathrm{L}$. & $\bullet$ \\
\hline $\mathrm{s}$ & Papaver argemone $\mathrm{L}$. & $\diamond$ \\
\hline s & Papaver dubium $\mathrm{L}$. & $\diamond$ \\
\hline $\mathrm{s}$ & Papaver rhoeas L. & $\checkmark$ \\
\hline En & Parietaria officinalis L. & - \\
\hline $\mathrm{s}$ & Pastinaca sativa L. s. str. & - \\
\hline En & Pisum sativum L., subsp. arvense (L.) & $\bullet$ \\
\hline & $\begin{array}{l}\text { Asch. \& Graebn. } \\
\text { Ranunculus arvensis L. }\end{array}$ & \\
\hline $\begin{array}{c}\mathrm{Vu} \\
\mathrm{S}\end{array}$ & $\begin{array}{l}\text { Ranunculus arvensis } \mathrm{L} . \\
\text { Raphanus raphanistrum L. }\end{array}$ & $\bullet$ \\
\hline \multirow[t]{3}{*}{ Crw } & Rhinanthus alectorolophus (Scop.) & $\bullet$ \\
\hline & Pollich, subsp. buccalis (Wallr.) & \\
\hline & Schinz \& Thell. & \\
\hline Crw & Rhinanthus serotinus (Schönh.) & - \\
\hline & Oborný, subsp. apterus (Fr.) Hyl. & 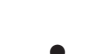 \\
\hline $\begin{array}{c}\text { Crp } \\
\mathrm{s}\end{array}$ & Scandix pecten-veneris L. & $\bullet$ \\
\hline $\mathrm{s}$ & Scleranthus annuus L. & $\bullet$ \\
\hline
\end{tabular}




\begin{tabular}{|c|c|c|}
\hline DoE & Name of species & Habitat \\
\hline li & Sclerochloa dura (L.) P. Beauv. & घ \\
\hline $\mathrm{s}$ & Senecio vulgaris L. & $\diamond$ \\
\hline $\mathrm{i}$ & Setaria pumila (Poir.) Roem. \& Schult. & $\diamond$ \\
\hline li & Setaria verticillata (L.) P. Beauv. & $\diamond$ \\
\hline $\mathrm{s}$ & Setaria viridis (L.) P. Beauv. & $\diamond$ \\
\hline $\mathrm{Vu}$ & Sherardia arvensis $\mathrm{L}$. & $\bullet$ \\
\hline En & Silene gallica $\mathrm{L}$. & $\bullet$ \\
\hline $\mathrm{s}$ & Sinapis arvensis L. & $\diamond$ \\
\hline $\mathrm{s}$ & Sisymbrium officinale (L.) Scop. & - \\
\hline li & Solanum alatum Moench & - \\
\hline li & Solanum luteum Mill. & - \\
\hline $\mathrm{Ld}$ & Solanum nigrum L. emend. Mill. & - \\
\hline $\mathrm{s}$ & Sonchus asper (L.) Hill & $\diamond$ \\
\hline $\mathrm{s}$ & Sonchus oleraceus L. & $\diamond$ \\
\hline s & Spergula arvensis L. subsp. arvensis & $\triangleright$ \\
\hline li & Spergula arvensis subsp. maxima & $\bullet$ \\
\hline $\mathrm{Vu}$ & Stachys annua (L.) L. & $\bullet$ \\
\hline Crp & Stachys arvensis (L.) L. & $\bullet$ \\
\hline $\mathrm{s}$ & Thlaspi arvense $\mathrm{L}$. & $\diamond$ \\
\hline Crp & $\begin{array}{l}\text { Thymelaea passerina (L.) Coss. \& } \\
\text { Germ. }\end{array}$ & $\bullet$ \\
\hline
\end{tabular}

\begin{tabular}{clc}
\hline $\mathrm{DoE}$ & \multicolumn{1}{c}{ Name of species } & Habitat \\
\hline $\mathrm{Vu}$ & Urtica urens $\mathrm{L}$. \\
$\mathrm{Ex}$ & Vaccaria hispanica (Mill.) Rauschert \\
$\mathrm{Vu}$ & Valerianella dentata (L.) Pollich \\
$\mathrm{Vu}$ & Valerianella locusta Laterr. emend. \\
& Betcke \\
$\mathrm{li}$ & Valerianella mixta Dufr. \\
$\mathrm{Vu}$ & Valerianella rimosa Bastard \\
$\mathrm{Ld}$ & Verbena officinalis $\mathrm{L}$. \\
$\mathrm{Vu}$ & Veronica agrestis $\mathrm{L}$. \\
$\mathrm{s}$ & Veronica arvensis $\mathrm{L}$. \\
$\mathrm{En}$ & Veronica opaca $\mathrm{Fr}$. \\
$\mathrm{Vu}$ & Veronica polita Fr. \\
$\mathrm{Ld}$ & Veronica triphyllos $\mathrm{L}$. \\
$\mathrm{li}$ & Vicia angustifolia L. var. segetalis \\
& (Thuill.) Serr. \\
$\mathrm{s}$ & Vicia hirsuta (L.) Gray \\
$\mathrm{Ld}$ & Vicia sativa L. \\
$\mathrm{Ld}$ & Vicia tetrasperma (L.) Schreb. \\
$\mathrm{s}$ & Vicia villosa Roth \\
$\mathrm{s}$ & Viola arvensis Murray \\
\hline
\end{tabular}

Explanations: DoE - degree of species endangerment: Ex - extinct in Poland, Crp - critically endangered of limited range in Poland, Crw - critically endangered in the whole range in Poland, En - endangered (above $80 \%$ of localities lost), Vu - vulnerable (near $50 \%$ of localities lost), Ld - with the number of localities decreasing, $\mathrm{s}$-with stable dynamics, $\mathrm{i}$ - expansion of species observed, sometimes invasive, li - lack of information about the species current dynamics; habitats: $\bullet$ - segetal species, - - segetal species with the tendency to occupy ruderal habitats, - ruderal species, - species of both ruderal and segetal habitats 